\title{
Tribological Properties and Machining Performance of Vegetable Oil Based Metal Working Fluids-A Review
}

\author{
Tamalapura Puttaswamy Jeevan, Saligrama Ramachandra Jayaram \\ Department of Mechanical Engineering, Malnad College of Engineering, Visvesvaraya Technological University, Karnataka, India \\ Email: jeevantpmce@gmail.com
}

How to cite this paper: Jeevan, T.P. and Jayaram, S.R. (2018) Tribological Properties and Machining Performance of Vegetable Oil Based Metal Working Fluids-A Review. Modern Mechanical Engineering, 8, 42-65.

https://doi.org/10.4236/mme.2018.81004

Received: November 26, 2017

Accepted: February 4, 2018

Published: February 7, 2018

Copyright (c) 2018 by authors and Scientific Research Publishing Inc. This work is licensed under the Creative Commons Attribution International License (CC BY 4.0).

http://creativecommons.org/licenses/by/4.0/

\begin{abstract}
Lubricants are playing an important role in world industrial and economic development, mainly by reducing friction and wear in mechanical contacts. The outlook for eco-friendly MWFs for the next decade is 15\% of global volume share. Due to ever increasing demand for environmentally acceptable products suitable for use as MWFs, vegetable oil-based MWFs are drawing the attention of researchers across the globe. Owing to the desirable properties of vegetable oils as cutting fluids, vegetable oil-based cutting fluids play an important role in conserving the environment by means of sustainability. This paper focuses on various vegetable oil being developed to promote biodegradable MWFs across the world. The performance of vegetable oils with respect to cutting and thrust force, tool wear, temperature, surface roughness in turning, drilling, milling and grinding a wide variety of materials are studied and reported. The review also throws light on the tribological behavior of vegetable oils that influence the lubricity in Metal working process. The review reveals that vegetable oils offer an alternative, eco-friendly and sustainable MFWs for the future of manufacturing.
\end{abstract}

\section{Keywords}

Metal Working Fluids, Vegetable Oils, Tribology, Eco-Friendly and Sustainable

\section{Introduction}

Metalworking fluids (MWFs) are used as a lubricant in machining processes to increase tool life, enhance machining efficiency and provide excellent surface quality and accuracy by means of both cooling and lubricating at the tool-workpiece in- 
terfaces [1]. More than $50 \%$ of all lubricants used globally are petroleum based and have adverse effects on environment due to improper disposal, toxicity and non-biodegradability. Hence, there is an increasing demand for environmentally acceptable and biodegradable products suitable for use as MWFs [2]. Environmental compatibility of cutting fluids is determined mostly with biodegradability. Biodegradability is the degradation by the action of microorganisms [3]. MWFs are classified as biodegradable if its percentage degradation in a standard test exceeds a target level. Vegetable oils offer $95 \%$ biodegradability, which helps in reducing the cost of disposal [4]. This demand has met to some extent by abundantly available vegetable oils. The use of edible oil to produce MWFs is not feasible in view of the big gap in demand and supply of such oil [5]. Non-edible oils like karanja, jatropha, mahua, castor oil, linseed oil, and neem are being considered as the source of straight vegetable oil [6]. The existence of some toxic ingredients in the non-edible vegetable oils made it unsuitable for human food. The forecast for eco-friendly/biodegradable MWFs for the next decade is a universal share of about $15 \%$ and may reach to $30 \%$ in some regions [7]. The world metalworking industries have to face a major economic and environmental challenge, and it certainly will remain as an interesting area of research [8]. Figure 1 shows the adverse effects of mineral oil with respect to global warming potential impact on the environment by different MWFs. Vegetable oil-based MWFs are emerging as potential replacements [9] [10].

The performances of a variety of mineral and vegetable oil-based MWFs in a vast range of machining operations are evaluated [12] and found that vegetable-based oil formulations show better performance than the commercial mineral oil in all operations. The development of vegetable oil-based MWFs, modification of raw vegetable oil and contributions from researchers in the field of eco-friendly MWFs as an alternate source in the Metal Working process is reviewed.

\section{Development of Vegetable Oil Based Metal Working Fluids}

Vegetable and animal oils were used by the early men as a source of cutting fluid

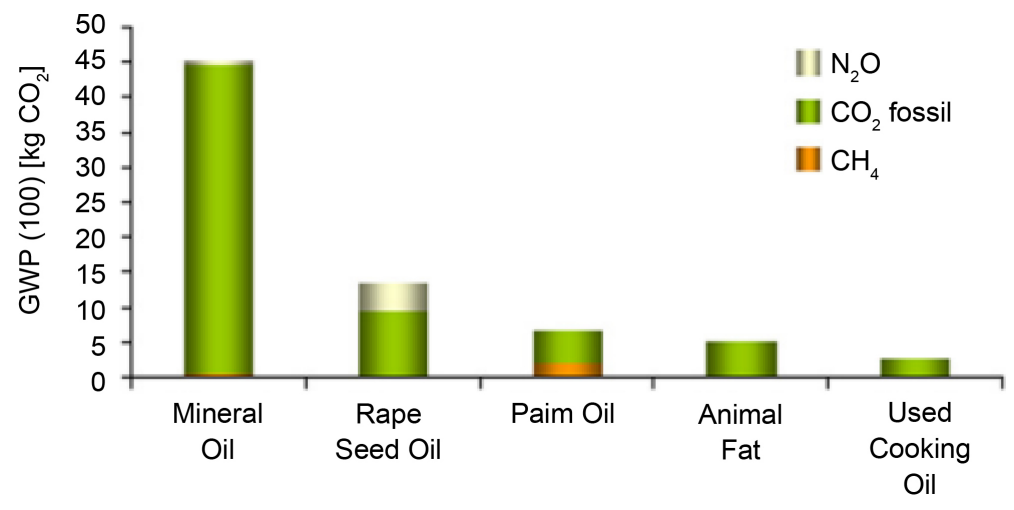

Figure 1. Impact on environment by different MWFs [11]. 
before the discovery of petroleum in the 1850's. The use of cutting fluids in machining was first reported in 1894 by F. Taylor, who noticed that cutting speed could be increased up to $33 \%$ without reducing tool life by applying large amounts of water in the cutting zone [13].

Between 1900 and till date, more researchers were being reported on the effect of vegetable-oil-based metalworking fluid in machining ferrous, non-ferrous metals and super alloy materials [14]. Research on biodegradable functional fluids emerged as one of the top priorities in lubrication in the early 1990's which led to a lot of growing number of environmentally friendly fluids and lubricants in the market [15]. The demand for bio-based lubricants was $0.50 \mathrm{Mt}$ in 2011, which is expected to be increased to $0.79 \mathrm{Mt}$ in 2018 (Synthetic and Bio-Based Lubricants-Global Industry Size, Market Share, Trends, Analysis and Forecast, 2012-2018, 2013). This analysis and forecast indicate that biodegradable lubricants are slowly replacing the synthetic lubricants [16].

Research developments in the application of vegetable-oil-based metalworking fluids in machining processes have endorsed a great consideration in recent days, this being due to the favorable properties of vegetable-oil-based as metal working fluids [17]. Several areas of development are under investigation, but, mainly, research effort is concentrated on biodegradable cutting fluids and methods for waste disposal [18]. The demand for biodegradable, environmentally gentle lubricants especially in eco-friendly responsible areas are expanding. There is a potential for developing novel biodegradable and ecologically harmless base stocks for a new generation of lubricants.

\section{Properties of Vegetable Oils}

Vegetable oil offers properties desirable for MWFs such as a high viscosity index, high lubricity, low volatility [19] [20] [21] and advanced properties including low toxicity and high biodegradability [22]. Vegetable oils primarily consist of triglycerides [23] [24]; the triacylglycerol structure in vegetable oil has molecules which arrange themselves in such a manner to make a closed packed monomolecular layer which enhanced the surface film, makes it a strong competitor as a base stock for MWFs and functional fluids [25] [26] [27]. The chemical composition and fatty acid profiles of vegetable oils (VO) are the primary reasons behind their performance as cutting fluid. Long, polar fatty acid chains provide high strength lubricant films that interact strongly with metallic surfaces, reducing both friction and wear [28]. The high molecular weight provides low volatility and better viscosity properties.

The raw versions of vegetable oils are not readily suitable for the MWFs because of its poor thermo-oxidation due to the presence of bis-allylic protons. When oil oxidation occurs, oil viscosity and acid content increase, corroding metal parts, generating sludge and as a consequence, reducing the efficiency. In addition, many researchers admitted that most vegetable oils undergo precipitation, cloudiness, solidification, poor corrosion protection and poor flow under 
the severe condition of temperature, pressure, and environment [29] [30]. The performance limitation of vegetable-based lubricant stem from inherent inferior physicochemical properties to those based on mineral oil. A lot of research and development is being carried out to overcome the limitations of vegetable oils for use as lubricants.

Many contributions are cited for improving the tribological properties of vegetable oils with the aid for various anti-wear, anti-oxidant, extreme pressure additives. Few of important contributions related to MWFs are discussed below.

\section{Tribological Properties}

Tribological investigations are reported on the raw/modified vegetable oil-based MWFs. Most of the studies were under high frequency reciprocating test rig (HFRR), pin-on-disc and four-ball tester.

Adhvaryu et al. [31], studied the effect of vegetable oil structure and additive components on friction and wear, was done using a ball-on-disk configuration. Quantification of wear track scar width, and the coefficient of friction (Figure 2) coupled with the analysis of the wear track by SEM gives a fairly good insight into the extent of wear protection of chemically modified soybean oil (CMSBO) when compared to raw soybean oil (SBO) or thermally modified soybean oil (TMBSO) under similar experimental conditions.

Alves et al. [32], studied the effect of adding oxides nanoparticles ( $\mathrm{ZnO}$ and $\mathrm{CuO}$ ) as additives with conventional lubricant and two vegetable oil based lubricant (epoxidized Soybean and Sunflower oil). HFRR was used to investigate the friction and wear performances of lubricants. The anti-wear behavior of the oxide nanoparticles depends on the lubricant base oil. The nano-additives did not show good anti-wear ability when combined with epoxizided vegetable oil like sunflower and soybean oils as shown in Figure 3, because of the influence of the chemical nature of vegetable oil on film formation due to polar groups that

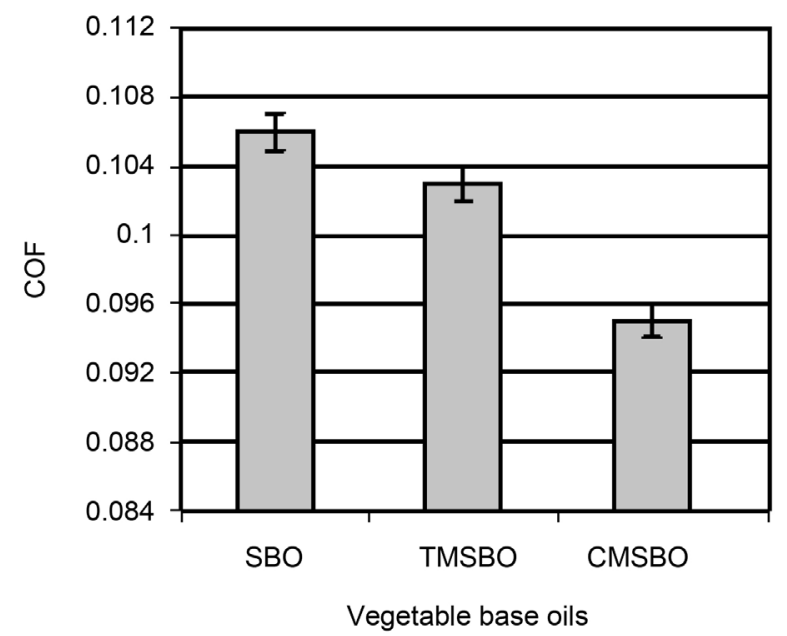

Figure 2. Friction coefficient of vegetable based oil and derivatives [31]. 


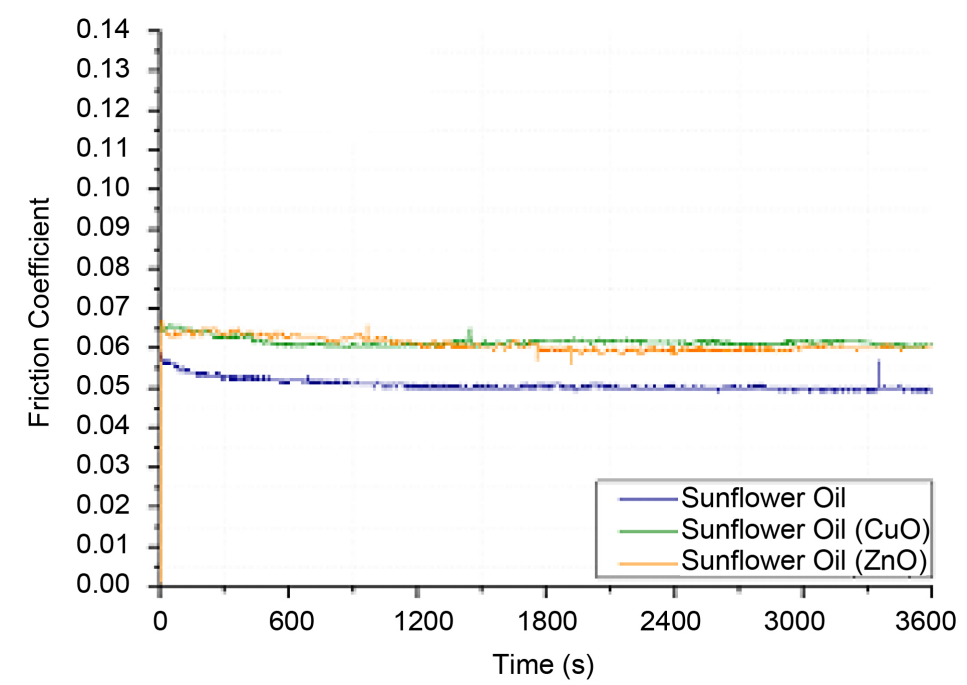

(a)

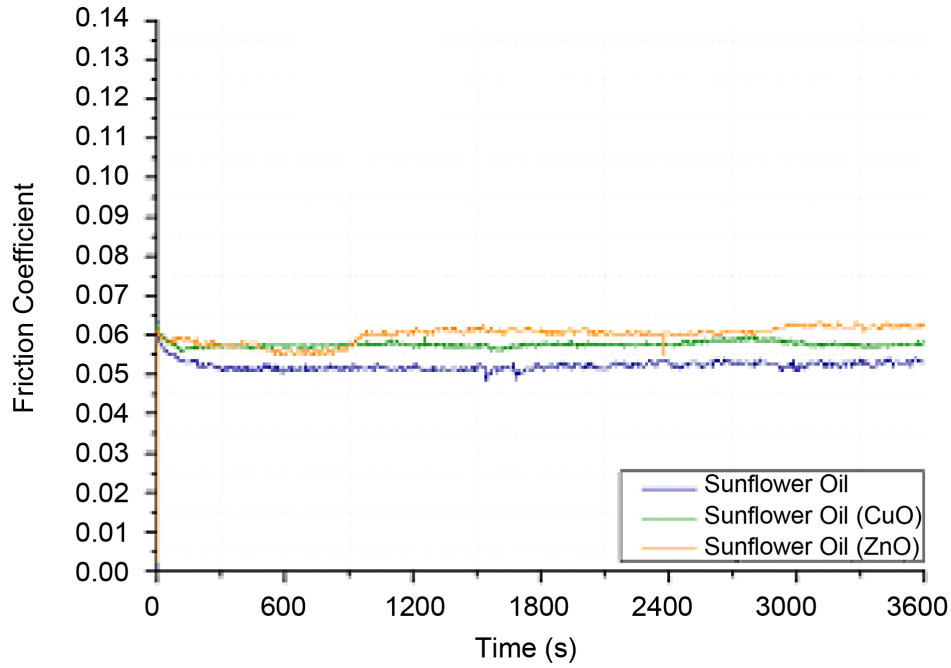

(b)

Figure 3. Friction coefficients as functions of time lubricated with (a) Sunflower oil (b) Soyabean oil-without and with nanoparticles additive [32].

adhere to surface. In this case, the nanoparticles have a third body behavior increasing the friction.

Quinchia et al. [33], carried out tribological studies on high oleic sunflower (HOSO), soybean (SYO) and castor (CO) oils. It has been found that castor oil shows the best lubricant properties, when compared to high oleic sunflower and soybean oil, with very good film-forming properties and excellent friction and wear behavior. Figure 4 shows the friction coefficient and wear scar obtained by HFRR.

Syahrullail et al. [34], compared the wear scar diameter of the ball bearings lubricated with the $100 \%$ palm oil fatty acid (PFAD), 100\% commercial hydraulic oil and a mixture of PFAD and Hydraulic oil. Since the palm fatty acid distillate carries the oxygen bond, it causes the oxidation on the surface of the ball bearing and made the structure brittle with producing the highest wear 

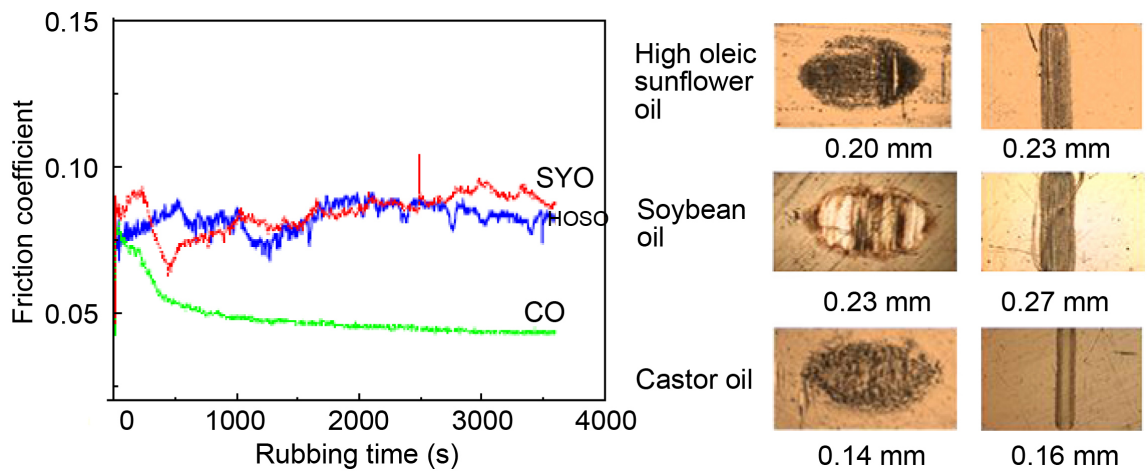

Figure 4. Friction coefficient and wear scars for the neat vegetable oils studied at $100^{\circ} \mathrm{C}$ [33].

scar diameter.

Tribological properties of nano-lubricants formulated from vegetable (coconut) oil and a mineral oil (paraffin oil) are compared using a modified pin-on-disc tribometer and a four-ball tester, under the boundary/thin film lubrication regime. The friction-reduction and anti-wear properties of the Molybdenum disulfide $\mathrm{MoS}_{2}$ nano-lubricants have been experimentally studied at ambient $\left(30^{\circ} \mathrm{C}\right)$ and at elevated temperatures upto $120^{\circ} \mathrm{C}$, for various concentrations of nanoparticles. $\mathrm{MoS}_{2}$ nano-lubricants applied at the sliding interface (Al-Steel) of the modified pin-on-disc tribometer induce less friction and wear rate compared to the base lubricants and this friction and wear reduction properties continues to increase in concentration of nano-additives in the lubricants till the optimum concentration of $0.53 \%$ for coconut oil and $0.58 \%$ for paraffin oil are reached (Figure 5 ).

The coefficient of friction (COF) and wear scar diameter (WSD) of crude jatropha oil (CJO), modified jatropha oil (MJO), jatropha methyl ester (JME) and commercial synthetic ester (SE) was measured by using four ball tester by (Talib and Rahim, 2016). Figure 6 shows the result of WSD and COF for CJO, MJO1 (JME:TMP; 3.1:1), MJO 3 (JME:TMP; 3.3:1), MJO5 (JME:TMP; 3.5:1) and SE. It is observed that the tribology behavior is related to the lubricant viscosity. CJO poses the lowest WSD due to its high viscosity. Meanwhile, the WSD of MJO5 reduces $19.73 \%$ when compared to the SE. MJO5 promise to reduce the wear between the contact surfaces of the steel balls. The WSD of modified oils slightly increases as the viscosity decreased. Moreover, the MJO5 showed the lowest COF compared to all samples. The COF values for modified oils were slightly smaller than the SE and CJO.

\section{Performance of Vegetable Oil Based Metal Working Fluids}

Various authors have carried out research with vegetable oils as alternate cutting fluids in machining of a wide variety of materials their experimental results obtained in terms of cutting and thrust force, tool wear, temperature, surface roughness are discussed in this section. 


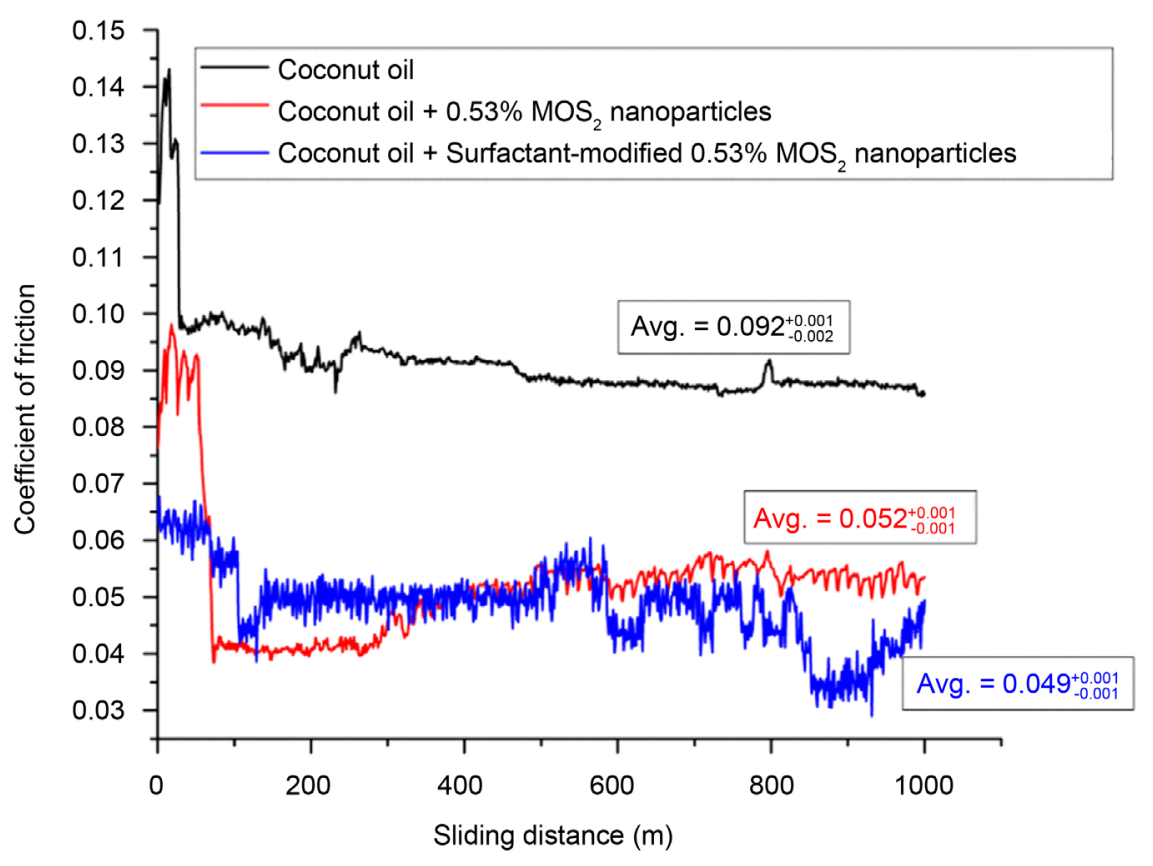

(a)

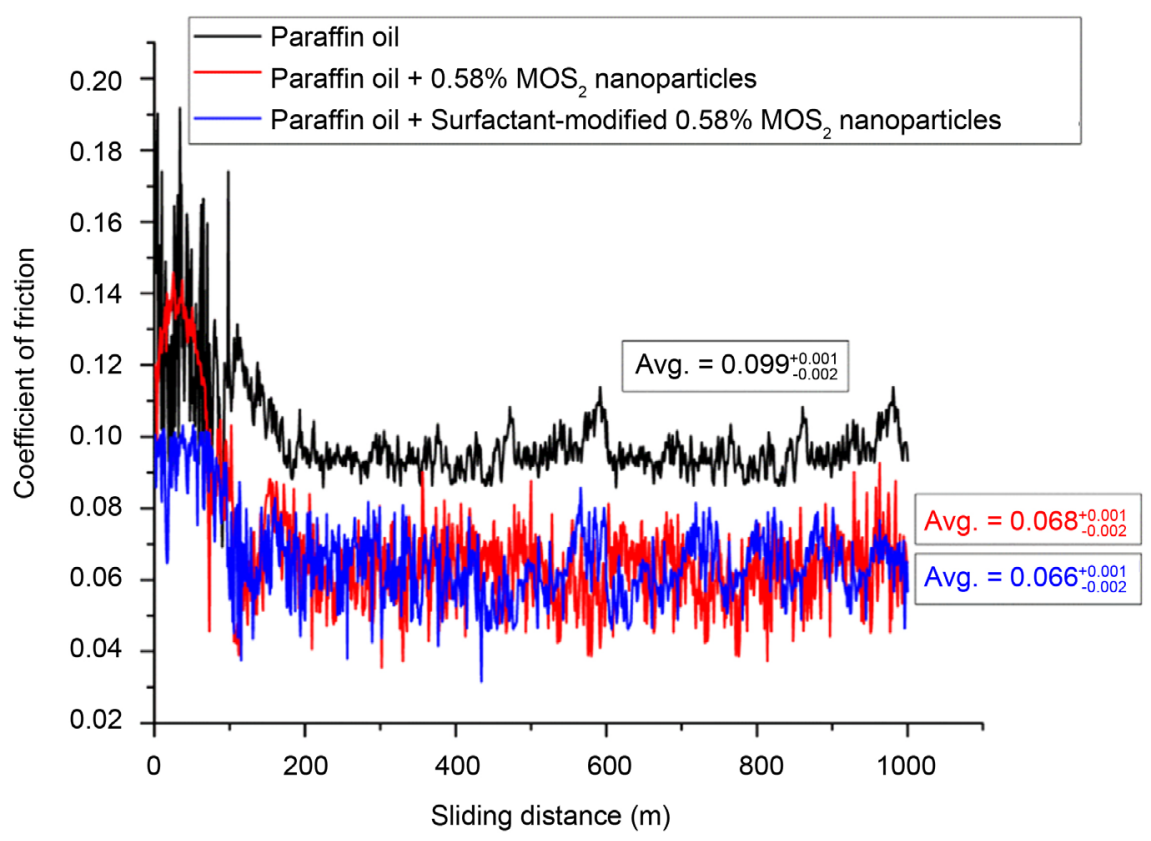

(b)

Figure 5. Coefficient of friction vs sliding distance for (a) Coconut oil nano-lubricants (b) Paraffin oil nano-lubricants [35].

\subsection{Cutting and Thrust Force}

Cutting forces are considered as important parameters in turning operation and they dictate the power required for machining [37]. The thrust force influences the dimensional accuracy, tool wear, and machining system stability. Type of cutting fluids used in machining process has significant influence (51.1\%) on the cutting force. The application of cutting fluid is believed to reduce the friction 


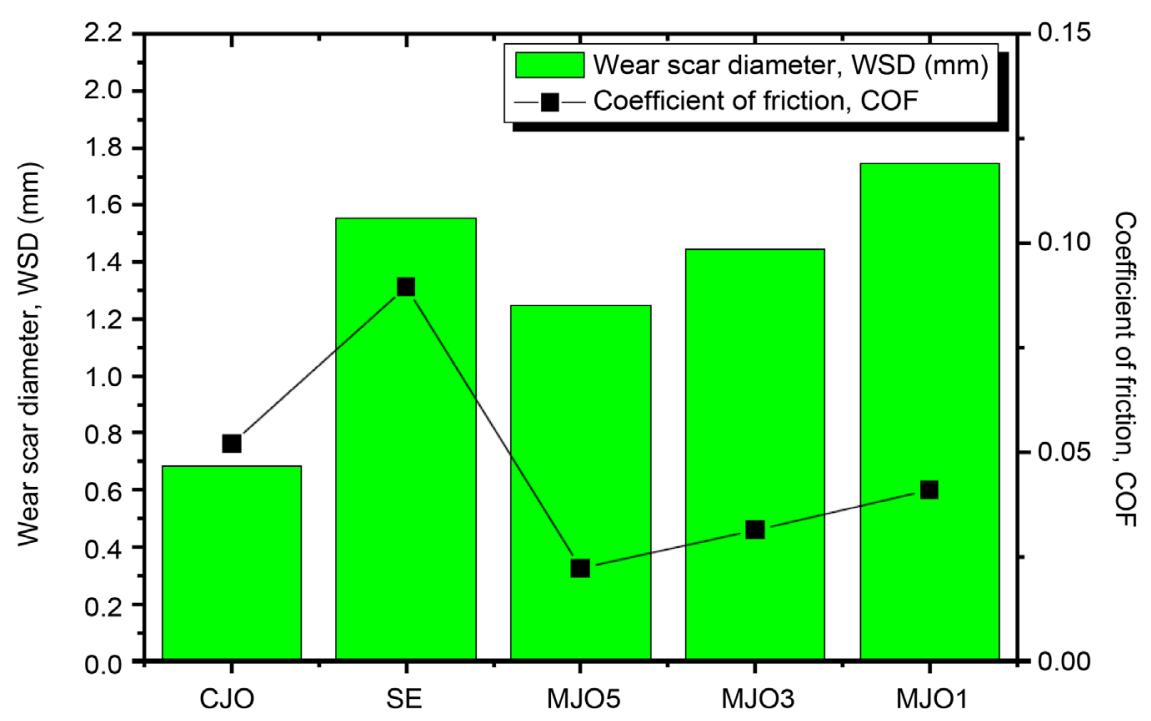

Figure 6. Wear scar diameter and coefficient of friction for all samples [36].

coefficient between the tool-workpiece interfaces and hence there is a significant cutting force reduction.

Ozcelik et al. [38], experimentally evaluated the performances of refined sunflower (SCF) and canola oils (CCF) including different percentage of extreme pressure (EP) additive and two commercial cutting fluids in turning processes. VBCFs were able to work on stainless steel as good as commercial mineral cutting fluids (CMCF) and also the values of cutting forces were found to be superior to that of commercial semi-synthetic cutting fluids (CSSCF) as shown in Figure 7.

The effect of formulated cutting fluids (palm kernel oil and cottonseed oil) on cutting force in turning AISI 4340 steel with coated carbide using Taguchi method was investigated [39] and compared with conventional (mineral) oil-in-water emulsion cutting fluid. Palm kernel oil and cottonseed oil were ranked first and second, followed by mineral oil with respect to the cutting forces generated while machining.

Padmini et al. [40], studied the effectiveness of vegetable oil based nanofluids as cutting fluids in turning AISI 1040 steel through MQL. Different samples of nanofluids are formulated using dispersions of nanomolybdenum disulphide $\left(\mathrm{nMoS}_{2}\right)$ in coconut (CC), sesame (SS) and canola (CAN) oils at varying nanoparticle inclusions (npi). Cutting forces are approximately reduced by $37 \%$ by using $\mathrm{CC}+\mathrm{nMoS}_{2}$ at $0.5 \%$ npi compared to dry machining (Figure 8).

Talib and Rahim [41], evaluated the performance of chemically modified crude jatropha oil (MJO) and crude jatropha oil (CJO) as bio-based metalworking fluids for machining process. The results obtained were compared with synthetic ester (SE), where the performance of the MJO was comparable with SE in terms of cutting force. (Figure 9)

Drilling medium carbon steel by HSS drill bit [42] with vegetable oil based 


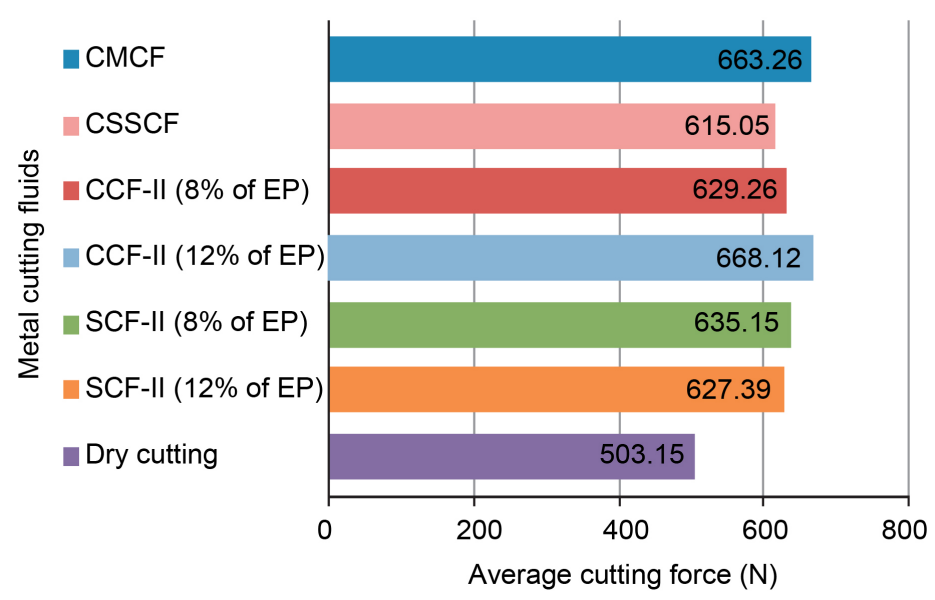

Figure 7. Effects of metal cutting fluids on average cutting forces [38].

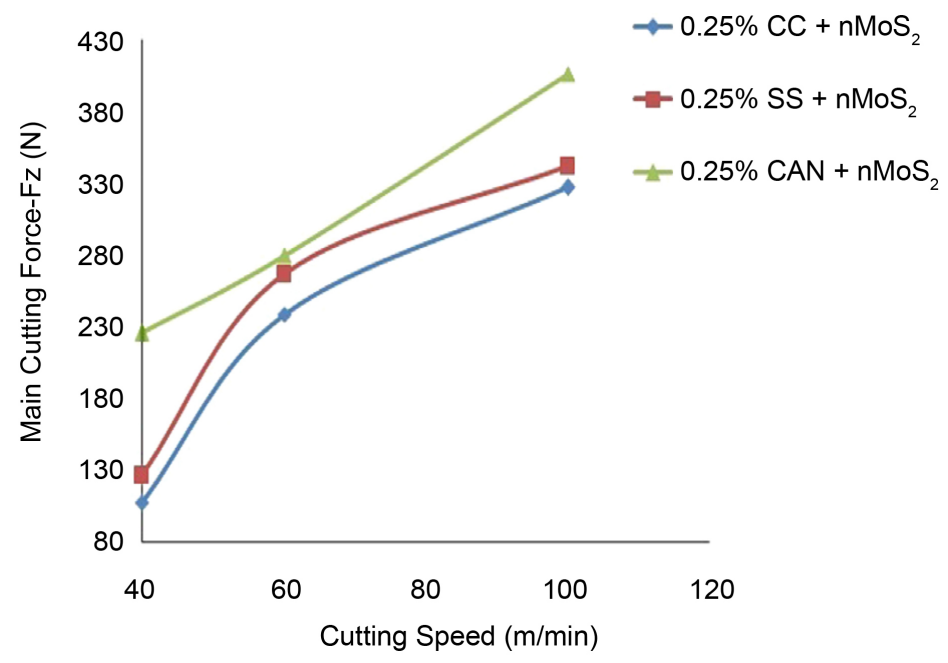

Figure 8. Variation of main cutting force with speed (feed: $0.14 \mathrm{~mm} / \mathrm{rev;}$ time: $16 \mathrm{~min}$; d.o.c: $0.5 \mathrm{~mm}$ ) [40].

cutting fluid reduces more cutting force and torque by $6 \%$ and $8 \%$, respectively than conventional cutting fluid (Figure 10). The raw and refined sunflower oils based Cutting Fluids showed lesser thrust force than commercial cutting fluids in the drilling of AISI 304 austenitic stainless steel [43].

Ojolo et al. [44], experimentally determined the effect of some straight vegetable oils (groundnut oil, coconut oil, palm kernel oil and shear butter oil) on cutting force during cylindrical turning of mild steel, copper and aluminum using tungsten carbide tool. It is observed that the effects of the bio-oils on cutting force were material dependent. Groundnut oil exhibited the highest reduction in cutting force while turning aluminium. Palm kernel oil had the best result when copper was turned. However, at higher feeds, groundnut oil had the best result for copper. Coconut oil recorded the highest cutting force in all the three materials machined followed by shear butter oil and as such, were very mild in reducing cutting force during cylindrical machining. 


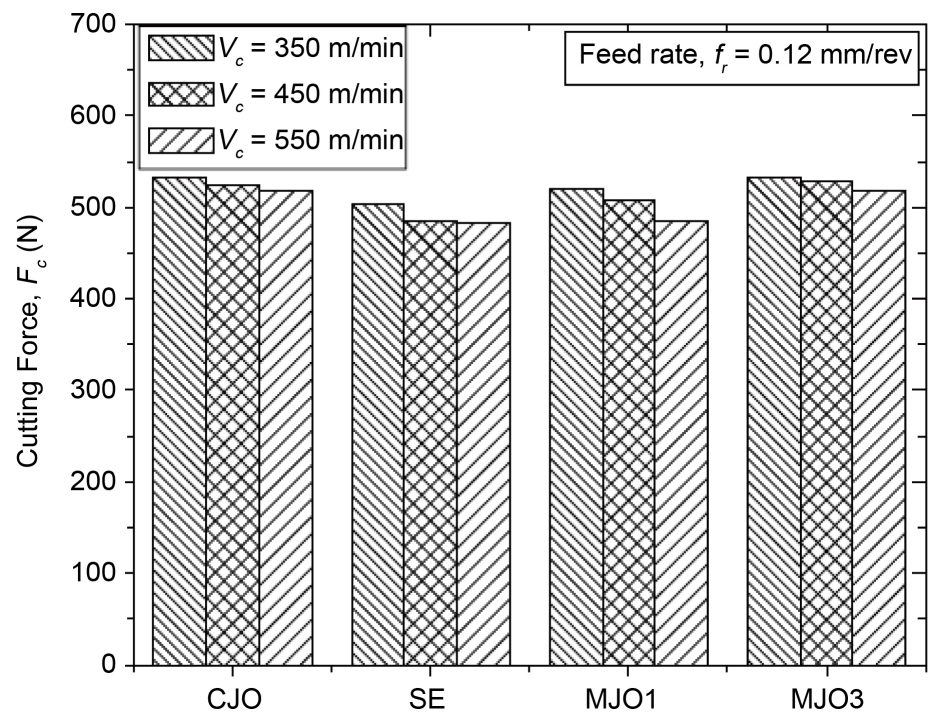

Figure 9. Cutting force for bio-based cutting fluids at feed rate of 0.08 $\mathrm{mm} / \mathrm{rev}$. [41].

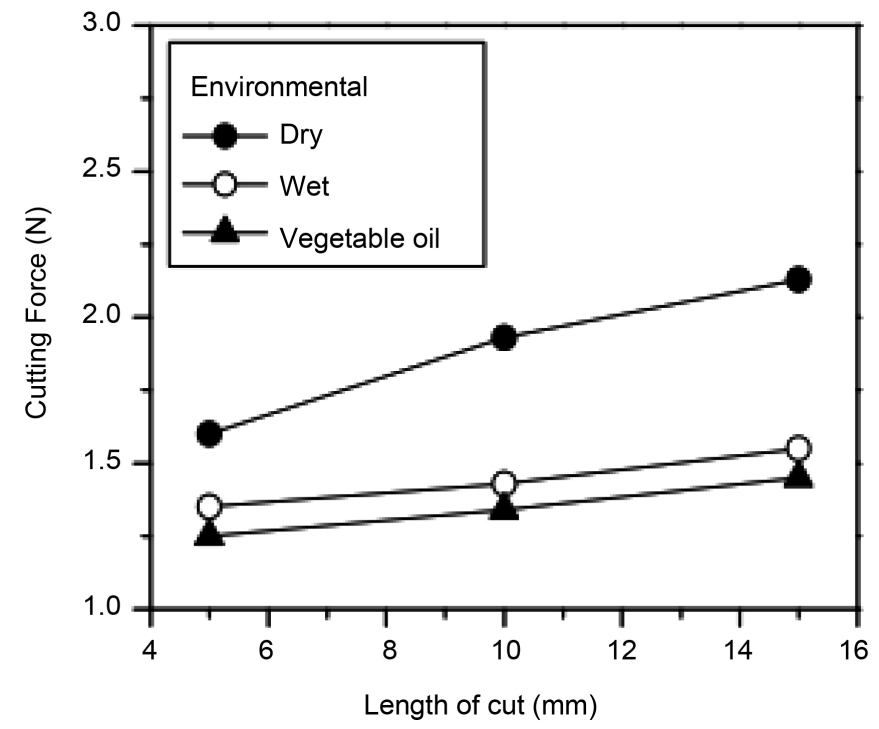

Figure 10. Drilling force versus length of cut for different cutting environments [42].

\subsection{Tool Wear}

The cutting tool wear mainly affects the tool life and the surface quality of the finished product. The most reported wear patterns are flank wear and crater wear. The possibility of predicting tool wear is thus necessary to avoid catastrophic tool failure, which affects the machining performance as well as the final part quality [45].

Xavior and Adithan, observed a considerably lesser tool wear with coconut oil when compared to soluble oil and straight cutting oil at lower cutting speed for turning of AISI 304 as shown in Figure 11. Moreover, the viscosity of coconut oil is more than that of soluble oil and less than that of straight cutting oil, which 


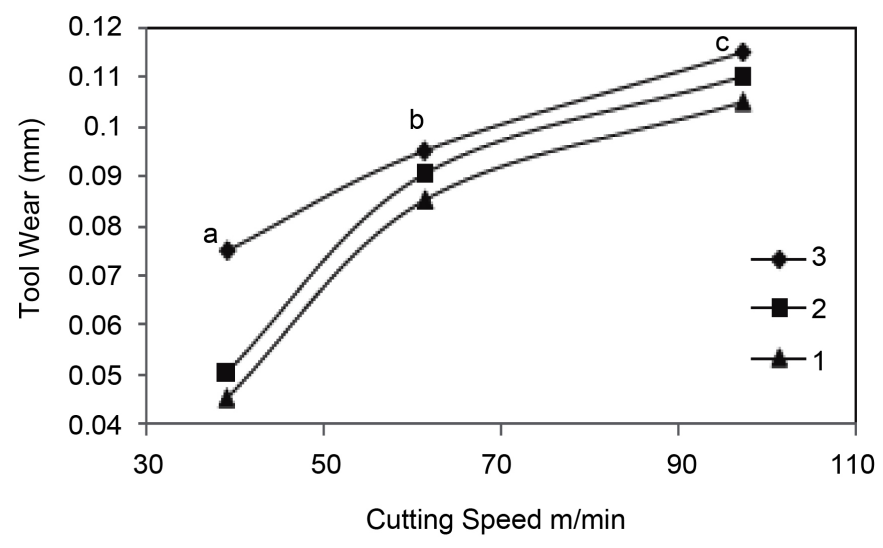

Figure 11. Cutting speed vs. tool wear for (1) coconut oil, (2) soluble oil, (3) straight cutting oil at feed rates of (a) $0.2 \mathrm{~mm} / \mathrm{rev}$, (b) $0.25 \mathrm{~mm} / \mathrm{rev}$ and (c) $0.28 \mathrm{~mm} / \mathrm{rev}$ and constant depth of cut $0.5 \mathrm{~mm}$ [46].

favors the easy flow of cutting fluid at minimal oil condition.

Flank wear versus cutting time for different cutting fluids are shown in Figure 12. For dry cutting, CSSCF and CMCF, flank wear increased rapidly with the machining time and wears reached their catastrophic values in a shorter time. But, flank wear increased at a lower rate when using VBCFs. CCF-II ( $8 \%$ of EP) also gave a lower tool wear rate in comparison to the other cutting fluids. Tool life was above 6000s when turning with CCF-II ( $8 \%$ of EP); while at the same machining condition, tool lives of dry cutting, CSSCF and CMCF were only 200, 1000 and 2000s, respectively. Using VBCFs, the tool life increased 6 times and 3 times with respect to CSSCF and CMCF, respectively.

MQL on milling of martensitic stainless steel is applied by using nano $\mathrm{MoS}_{2}$ reinforced vegetable cutting fluid, resulting in minimum tool wear. Vegetable oil can definitely replace a commercial cutting lubricant owing to the significant tool life performance and cutting forces when end milling AISI 420 steel using uncoated carbide tool [47].

Alves et al. [48], developed a castor oil based cutting fluid for grinding SAE 8640 using a vitrified CBN wheel, a significant reduction in radial wheel wear compared to semi-synthetic cutting fluid is observed.

Manoj Kumar and Ghosh [49] studied the effect of nano-engineered sunflower oil for grinding hardened AISI 52100 steel by a vitrified bonded alumina wheel to compare with soluble oil and ordinary sunflower oil. Nano-engineered sunflower oil helped in better retention of grit sharpness on the active surface of grinding wheel, which finally led to the substantial arrest of wheel wear rate.

Ariff et al. [50], studied the performance of palm oil and water based cutting fluids. The wear behavior of TiCN coated tools while turning T6061 Aluminum Alloy is evaluated for three different cutting speeds $(333,415$ and $517 \mathrm{~m} / \mathrm{min}$ ) and at two different cutting parameters; depth-of-cut, $\mathrm{d}$ and feed rate, $\mathrm{f}(\mathrm{d}=0.2$ $\mathrm{mm}, \mathrm{f}=0.4 \mathrm{~mm} / \mathrm{rev}$ and $\mathrm{d}=0.4 \mathrm{~mm}, \mathrm{f}=0.6 \mathrm{~mm} / \mathrm{rev}$ ). The wear rate of machining 


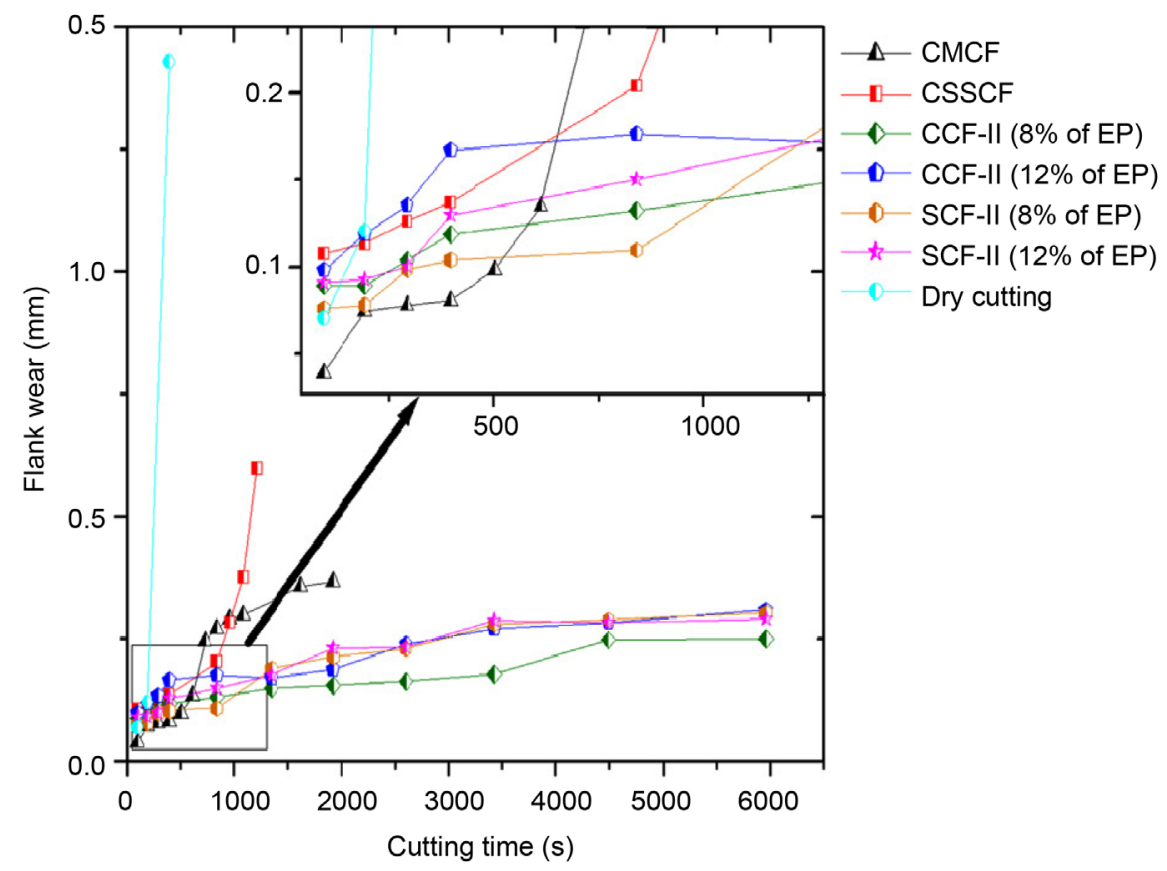

Figure 12. Variation of flank wear with respect to cutting time [38].

using palm oil is lower (longer tool life) than the wear rate obtained from using water based coolants. Palm oil has better lubrication properties compared to water based coolants which have a better cooling effect.

Krishna et al. [51], carried out machining under different lubrication conditions to assay the suitability of the coconut oil based nano-lubricants. The combined effect of solid lubricant and coconut oil leads to reduction in flank wear with $0.5 \%$ nano-boric acid particle suspensions compared to remaining conditions, the particles of solid lubricant flow at the interface with the oil and decrease the plastic contacts, leading to reduction of flank wear (Figure 13).

Khan et al. [52], studied the tool wear behavior while turning of AISI 9310 at three different machining conditions. The conditions tested are dry, wet and MQL using a vegetable oil. Figure 14 shows scanning electron microscope (SEM) image of auxiliary wear after machining for $43 \mathrm{~min}$. The image shows that the MQL by vegetable oil has a better reduction of groove wear growth. Relative to this, turning using MQL by vegetable oil resulted in the lower growth rate of flank wear compared to the wet and dry environments.

The effectiveness of micro lubrication was analyzed using a vegetable oil-based metalworking fluid during end milling AISI 1018 steel and it is possible to obtain higher tool life [53]. A comparable flank wear is seen under formulated Sunflower, Soybean, Canola, and Palm oil based soluble cutting fluid compared to mineral oil during milling [54].

\subsection{Surface Roughness}

The surface quality is an important parameter to evaluate the productivity of machine tools as well as machined components [55]. Surface roughness is a critical 


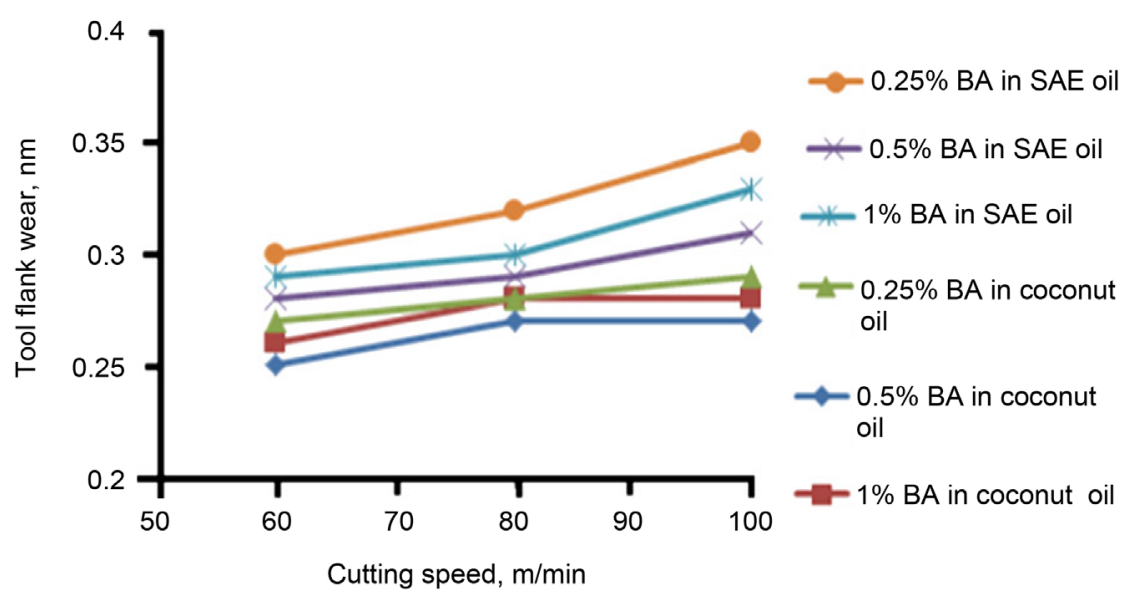

Figure 13. Variation of tool flank wear with cutting speed (feed $=0.2 \mathrm{~mm} / \mathrm{rev}$, d.o.c $=1$ $\mathrm{mm}$, time $=15 \mathrm{~min})[51]$.

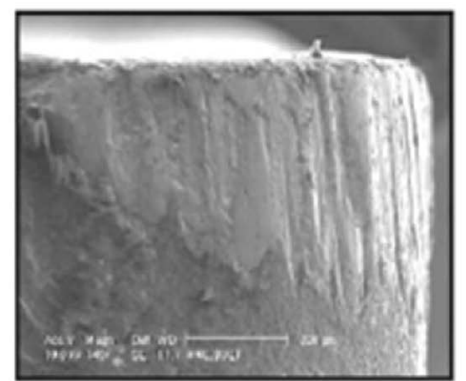

(a) Dry Machining

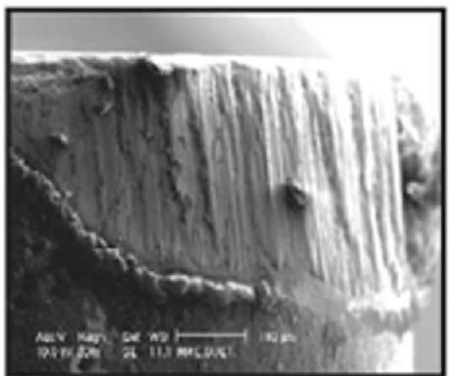

(b) Wet Machining

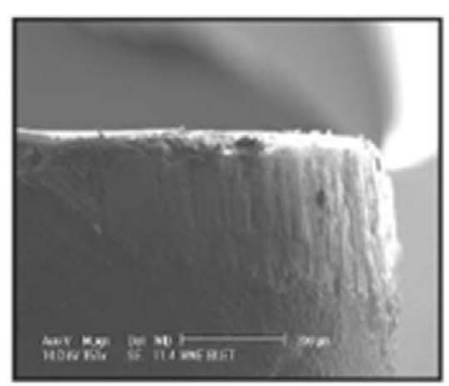

(c) MQL Machining

Figure 14. SEM View of the auxiliary flank wear [52].

quality indicator for the machined surfaces and has influence on several properties such as wear resistance, fatigue strength, coefficient of friction and corrosion resistance of the machined parts.

Coconut oil based cutting fluids is impressive in decreasing surface roughness at higher values of feed and depth of cut in comparison to dry and water based cutting fluids while turning of hardened AISI 52100 (Figure 15).

Figure 16, shows the surface roughness as a function of feed rate at a constant cutting speed and depth of cut for three different oils. The results show that coconut oil outperforms the other two cutting fluids when the surface roughness is considered. 


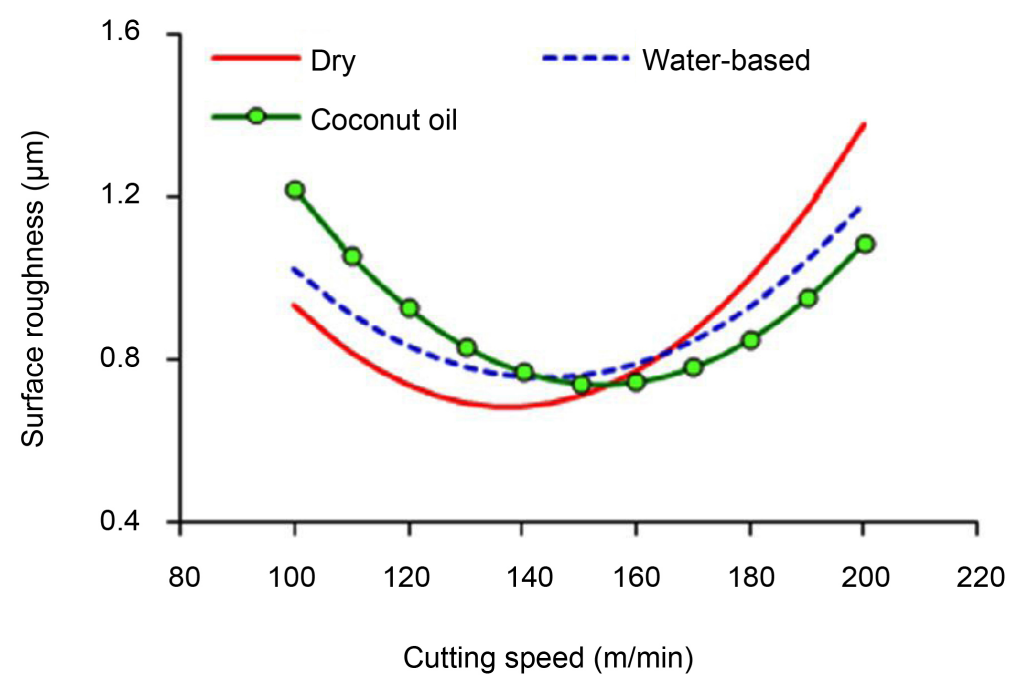

Figure 15. Effect of surface roughness with cutting speed [56].

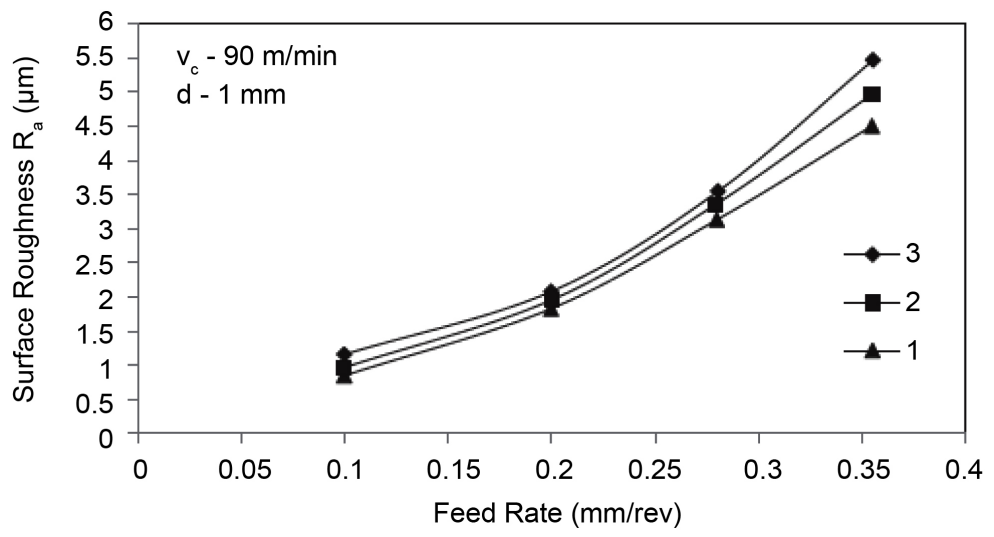

Figure 16. Surface Roughness as a function of Feed rate for (1) coconut oil, (2) soluble oil, (3) straight cutting oil [46].

Figure 17, shows that the roughness value under pure castor MQL is the maximum. The roughness values of all kinds of mixed base oil are slightly lower. Soybean/castor mixed base oil MQL obtains the minimum roughness values with Ra reaching $0.325 \mu \mathrm{m}$. The roughness values of rapeseed/castor mixed base oil and soybean/castor mixed base oil are quite close, with Ra value $0.334 \mu \mathrm{m}$. Minimal differences were observed between the roughness values of mixed base oil, peanut/castor, maize/castor, and palm/castor mixed base oil.

Sadeghi et al. [58], compared vegetable and synthetic ester oils on the basis of the surface quality properties that would be suitable for MQL applications. Figure 18 shows synthetic ester oil is found to be optimal cutting fluid for MQL grinding of Ti-6Al-4V with aluminium oxide $\left(\mathrm{Al}_{2} \mathrm{O}_{3}\right)$ grinding wheels.

Mahadi et al. [59], made use of VBCF blended with boric acid powder in turning AISI 431 steel. The addition of boric acid powder to palm kernel oil has yielded better surface finish compared to conventional mineral base oil. An average improvement of $7.21 \%$ in surface roughness was observed with Palm kernel 


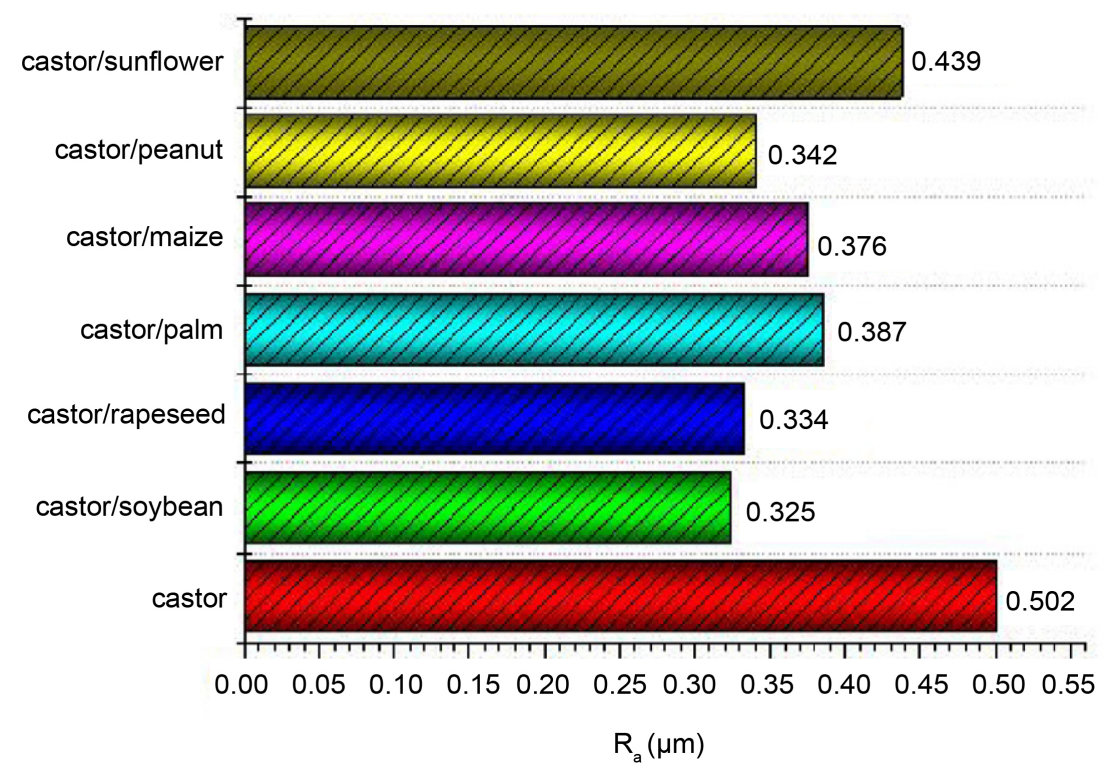

Figure 17. Ra values under different lubrications [57].

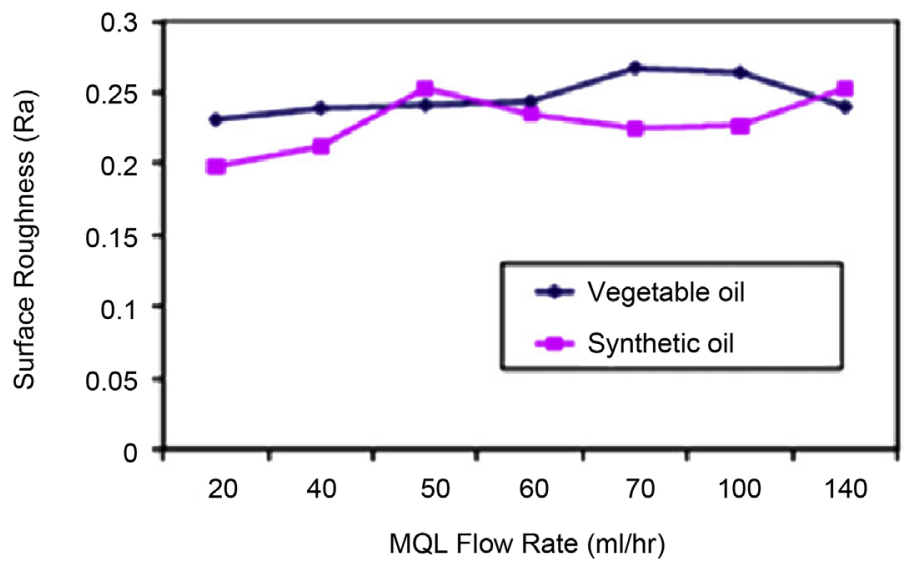

Figure 18. Effect of vegetable and synthetic oil with MQL modes on surface roughness [58].

oil based cutting fluid. It appears from Figure 19 that surface roughness grows quite fast under dry machining due to more intensive temperature and stresses at the tool-tips, MQL by vegetable oil appeared to be effective in reducing surface roughness. However, it is evident that MQL by vegetable oil improves surface finish depending upon the work-tool materials and mainly through controlling the deterioration of the auxiliary cutting edge by abrasion, chipping and built-up edge formation.

The raw and refined sunflower oils based Cutting Fluids showed better surface finish than commercial cutting fluids in the drilling of AISI 304 austenitic stainless steel [43]. A good surface roughness and surface integrity were obtained by using coconut oil in drilling AISI 316 stainless steel using HSS drill tool [60]. MQL on milling of martensitic stainless steel is applied by using nano $\mathrm{MoS}_{2}$ reinforced vegetable cutting fluid, resulting in better surface roughness [61]. 


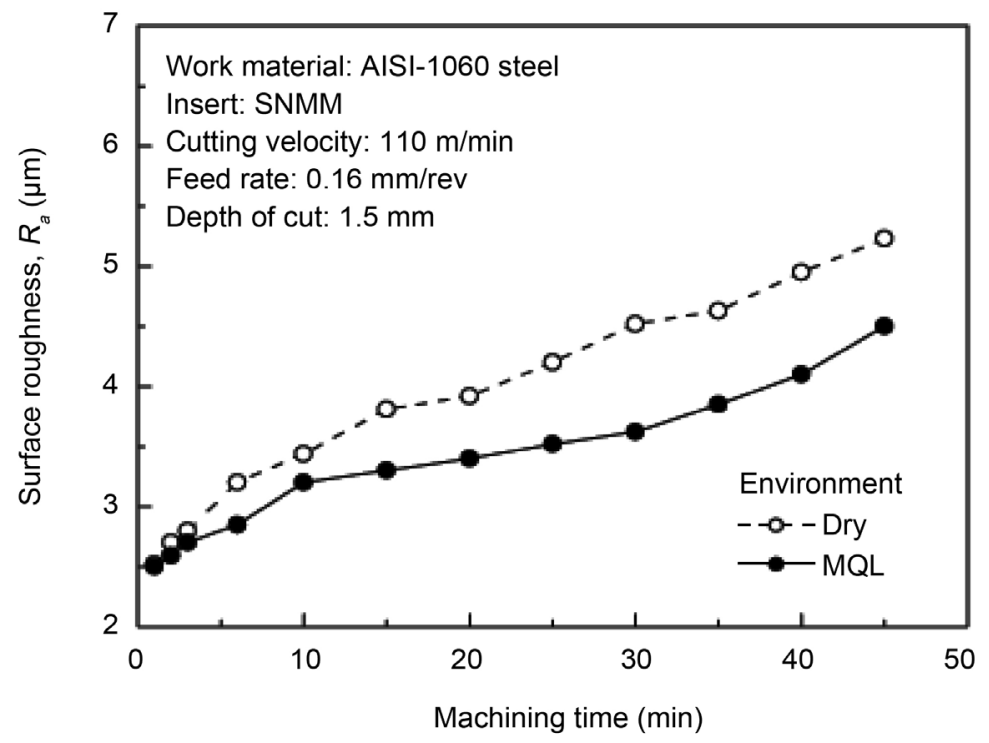

Figure 19. Surface roughness vs machining time under dry and vegetable oil (MQL) conditions [59].

\subsection{Temperature}

Temperature plays a vital role in the metal working industry today. With increasing cutting speeds being used in machining operations, the thermal aspects of cutting have become more important. The temperature not only directly influences the rate of tool wear, but also will affect the thermal expansion and final surface finish of a work piece material [62].

It is observed from Figure 20, that the heat transfer coefficient of coconut oil based lubricants is greater than the SAE-40 oil based lubricants. The high lubricating property of coconut oil is due to the fundamental composition of the vegetable oil molecules as well as the chemical structure of oil itself [53].

Effectiveness of three different types of vegetable oils with nano molybdenum disulphide additive in turning AISI 1040 steel is studied. Coconut (CC) oil resulted in low cutting temperatures as seen in Figure 21. Coconut oil with high percentage of saturated fatty acids and medium chain fatty acids, at higher temperatures enables formation of a high strength layer of lubricant which separates the surfaces in contact. The phenomenon of formation of vegetable oil film on the metallic surface is more significant in case of vegetable oils like coconut which have medium chain fatty acids unlike sesame (SS) and canola (CAN) which possess long chain fatty acids.

SE recorded slightly lower cutting temperature compared to MJO1 and MJO3. It is due to the high viscosity and lowest WSD value of SE. At the feed rate of $0.08 \mathrm{~mm} / \mathrm{rev}$, the SE recorded $2.37 \%$ and $5.57 \%$ reduction compared to MJO1 and MJO3 respectively. The trends were consistent for all feed rates. The reduction of percentage values was too small due to the lubricating film layer provided from MJO was strong and subsequently improved the machining performance by reducing the friction and machining temperature (Figure 22). 


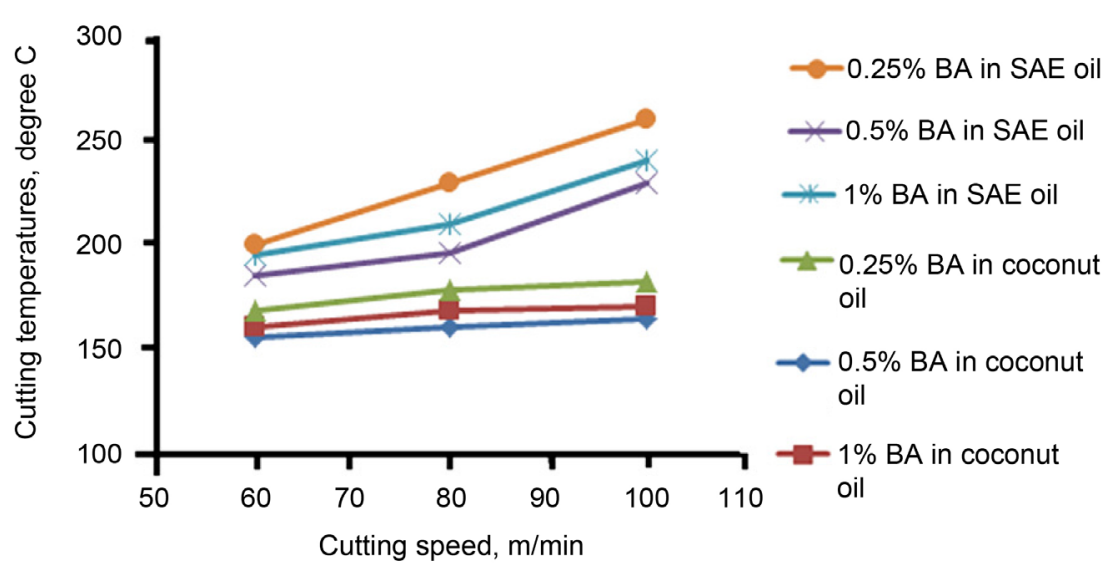

Figure 20. Variation of cutting temperatures with cutting speed.

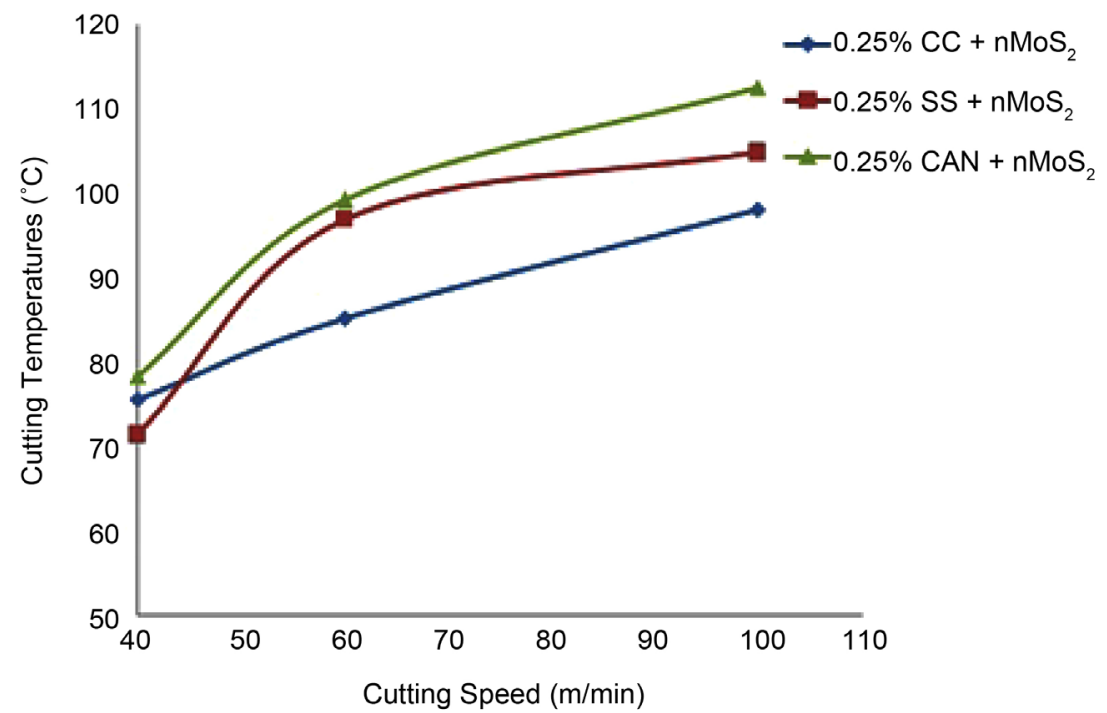

Figure 21. Variation of cutting temperatures with speed at feed: $0.14 \mathrm{~mm} / \mathrm{rev}$; time: 16 min; d.o.c: $0.5 \mathrm{~mm}$ [42].

The average chip-tool interface temperature was measured using the tool-work thermocouple technique and plotted against cutting velocity (Figure 23) for different feeds and environments undertaken. The present MQL systems enabled reduction in average chip-tool interface temperature up to $10 \%$ as compared to wet machining.

Rahim \& Sasahara [43], investigated the performance of MQL synthetic ester (MQLSE) and MQL Palm oil (MQLPO) under various cutting conditions. It is interesting that the values of temperature exhibited by the palm oil were relatively lower than the synthetic ester (Figure 24). This observation indicates that palm oil enhances heat dissipation in cutting tool. Furthermore, the high viscosity of palm oil helps to flow easily to the cutting zone at minimal quantity. This enables the reduction of friction between the tool and workpiece and subsequently reduced the heat. As a consequence, power consumption by using MQLPO can be minimized. 


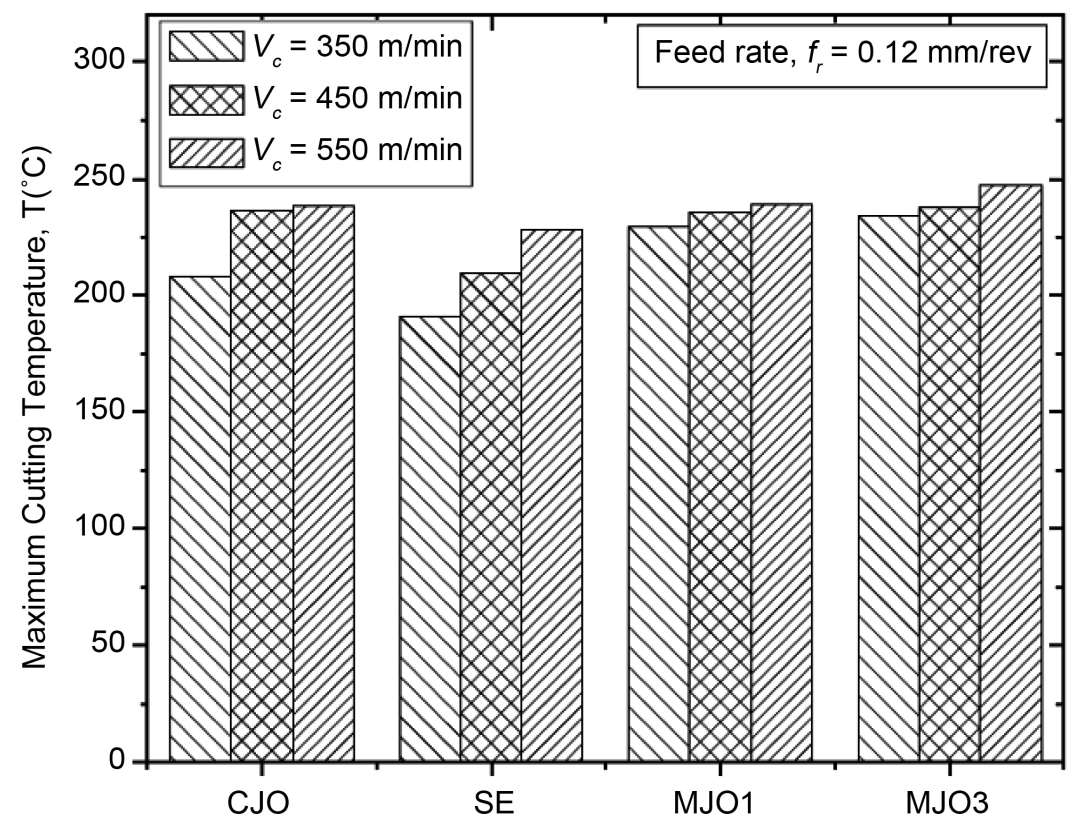

Figure 22. Maximum cutting temperature for different versions of jatropha oil and synthetic ester [43].

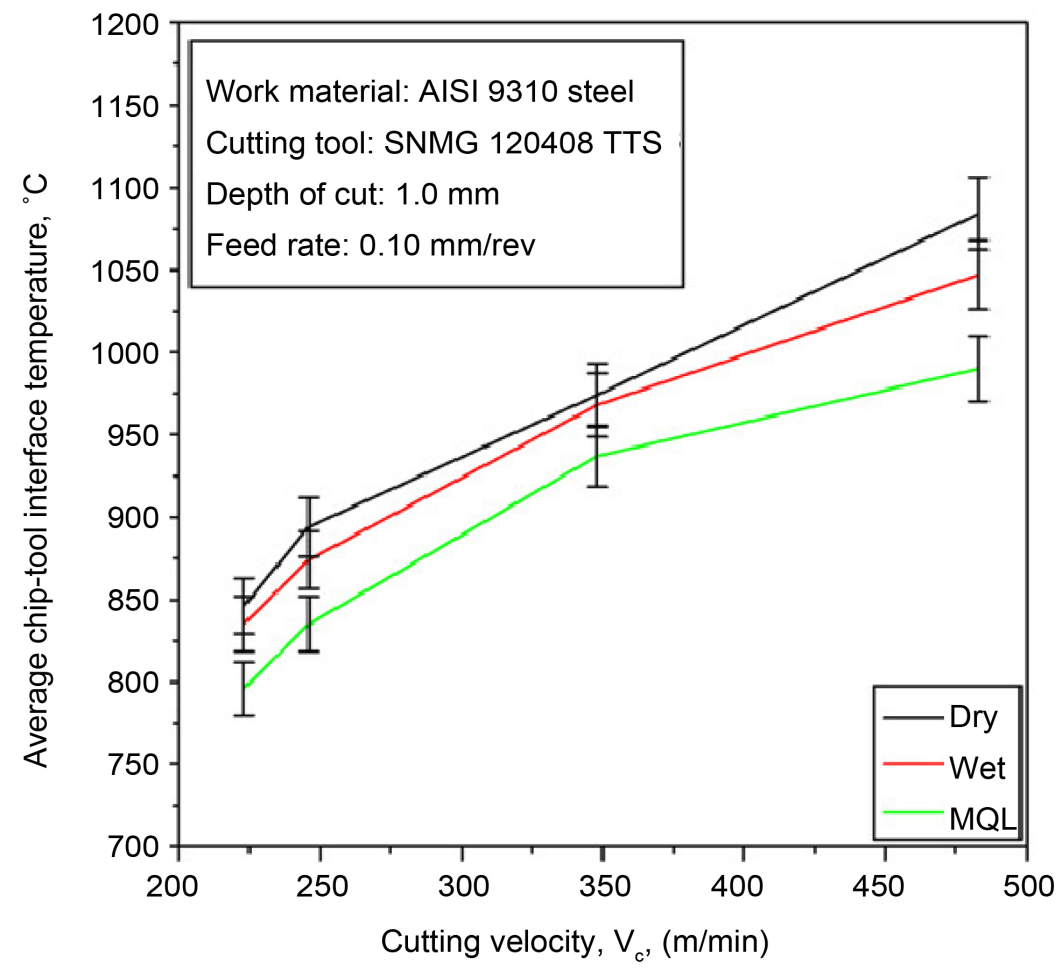

Figure 23. Variation in average chip tool interface temperature with cutting velocity [52].

\section{Future Perspectives of Vegetable Oil Based Metal Working Fluids}

Improving living standards in emerging economies, population growth, and the 


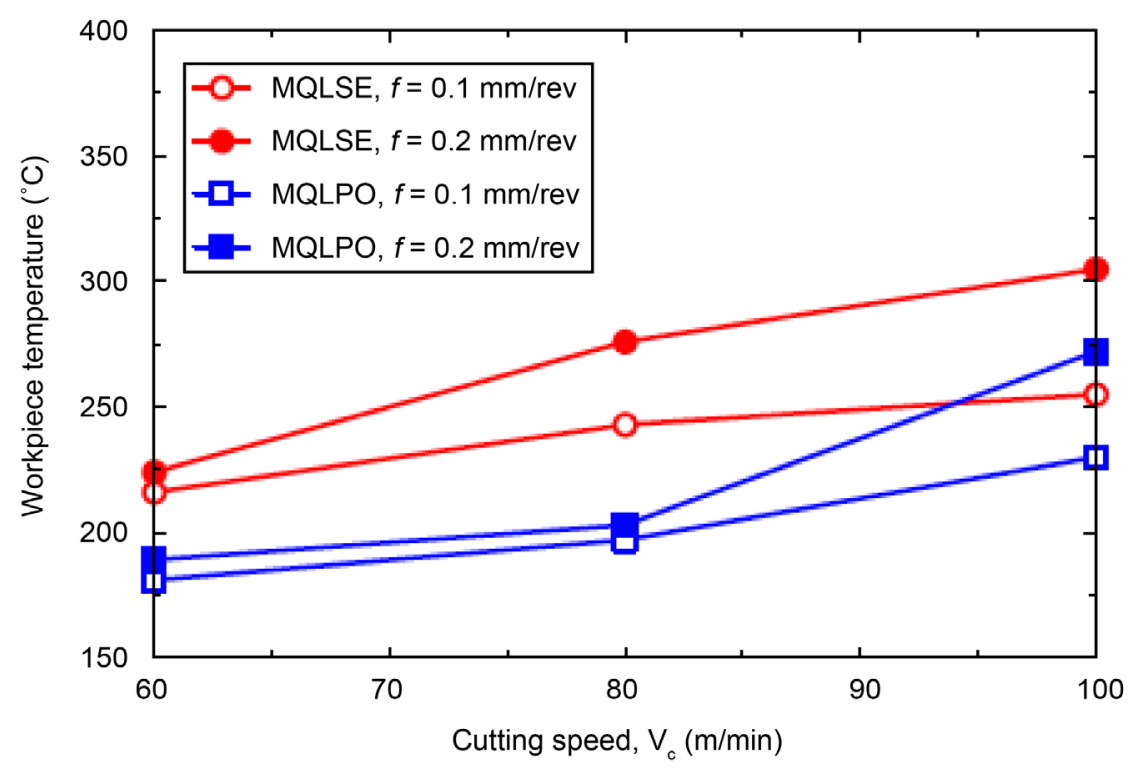

Figure 24. Maximum workpiece temperature for MQLSE and MQLPO at different machining conditions [43].

expansion of biolubricant are new trends that will have a major impact on the future development of this sector. Recycling the cutting fluids is also the need of the hour [32]. Matching additives and optimization of the proportions of components in the soluble oil formulations need further study [63]. Applications of vegetable oil-based fluids are not restricted to the manufacturing sector and can also be extended to a variety of biomedical applications such as surgical sealants and glues, wound healing devices, pharmacological patches, and drug carriers to scaffolds for tissue engineering [64]. The utilization of vegetable oils in the chemical industry has been the focus of much research [65]. Based on the excellent natural characteristics, vegetable oil derivatives are being used in numerous applications including adhesives, paints and coatings, and nanocomposites [66]. Use of Modified vegetable oil is strongly recommended to use in the polymer area [67]. Vegetable oils as biodegradable additives can be tried to improve the lubricating properties. Many more non edible vegetable oils are available across the globe. The utility of applying them as lubricants for various applications may be explored.

\section{Conclusions}

Investigations of various researchers with respect to tribological properties and machining performance of vegetable oils are reviewed and vegetable oil based cutting fluids are established to be favorable alternate to mineral oil based MWFs, because of their excellent lubricating properties. The thermal and oxidative stability of vegetable oil is limited and has been overcame by many researchers by making use of various additives and chemical modification process.

The review reveals that, it is difficult to rank the combination of lubricant and material for machining. An increased machining performance and lower envi- 
ronmental impact can be obtained with vegetable oils-based cutting fluids. Competitive performance of vegetable based cutting fluids improved product quality by reducing cutting force/thrust force, increasing surface quality, reduced tool wear and good heat dissipating ability.

The vegetable oils offer better future in the formulation of lubricants and contribute to cleaner manufacturing processes. They also encourage the agricultural practices and enhance the nations' economy.

\section{References}

[1] Talib, N. and Rahim, E.A. (2018) Performance of Modified Jatropha Oil in Combination with Hexagonal Boron Nitride Particles as a Bio-Based Lubricant for Green Machining. Tribology International, 118, 89-104.

https://doi.org/10.1016/j.triboint.2017.09.016

[2] Katna, R., Singh, K., Agrawal, N. and Jain, S. (2017) Green Manufacturing-Performance of a Biodegradable Cutting Fluid. Materials and Manufacturing Processes, 32, 1522-1527. https://doi.org/10.1080/10426914.2017.1328119

[3] Norrby, T. (2003) Environmentally Adapted Lubricants-Where Are the Opportunities? Industrial Lubrication and Tribology, 55, 268-274. https://doi.org/10.1108/00368790310496400

[4] Singh, Y., Pandey, A.K., Singh, N.K., Sharma, A. and Farooq, A. (2017) Sustainability of Polanga Oil Based Blended Lubricant at Different Load and Sliding Distance. Energy Sources, Part A: Recovery, Utilization, and Environmental Effects, 39, 1970-1977. https://doi.org/10.1080/15567036.2017.1393473

[5] Padhi, S.K. and Singh, R.K. (2011) Non-Edible Oils as the Potential Source for the Production of Biodiesel in India: A Review. Journal of Chemical and Pharmaceutical Research, 3, 39-49.

[6] Singh, Y., Singla, A., Upadhyay, A. and Singh, A.K. (2017) Sustainability of Moringa-Oil-Based Biodiesel Blended Lubricant. Energy Sources, Part A: Recovery, Utilization, and Environmental Effects, 39, 313-319. https://doi.org/10.1080/15567036.2016.1179360

[7] Nagendramma, P. and Kaul, S. (2012) Development of Ecofriendly/Biodegradable Lubricants: An Overview. Renewable and Sustainable Energy Reviews, 16, 764-774. https://doi.org/10.1016/j.rser.2011.09.002

[8] Li, F., Hanson, M.V. and Larock, R.C. (2001) Soybean Oil-Divinylbenzene Thermosetting Polymers: Synthesis, Structure, Properties and Their Relationships. Polymer, 42, 1567-1579. https://doi.org/10.1016/S0032-3861(00)00546-2

[9] Bisio, A.L. and Xanthos, M. (1995) How to Manage Plastics Wastes, Technology and Market Opportunities. Hanser, New York.

[10] Shashidhara, Y.M. and Jayaram, S.R. (2010) Vegetable Oils as a Potential Cutting Fluid-An Evolution. Tribology International, 43, 1073-1081. https://doi.org/10.1016/j.triboint.2009.12.065

[11] Sharma, J. and Sidhu, B.S. (2014) Investigation of Effects of Dry and Near Dry Machining on AISI D2 Steel Using Vegetable Oil. Journal of Cleaner Production, 66, 619-623. https://doi.org/10.1016/j.jclepro.2013.11.042

[12] Belluco, W. and De Chiffre, L. (2001) Testing of Vegetable-Based Cutting Fluids by Hole Making Operations. Tribology \& Lubrication Technology, 57, 12.

[13] Avila, R.F. and Abrao, A.M. (2001) The Effect of Cutting Fluids on the Machining 
of Hardened AISI 4340 Steel. Journal of Materials Processing Technology, 119, 21-26. https://doi.org/10.1016/S0924-0136(01)00891-3

[14] Lawal, S.A., Choudhury, I.A., Sadiq, I.O. and Oyewole, A. (2014) Vegetable-Oil Based Metalworking Fluids Research Developments for Machining Processes: Survey, Applications and Challenges. Manufacturing Review, 1, 22. https://doi.org/10.1051/mfreview/2014021

[15] Busch, C. and Backé, W. (1993) Development and Investigation in Biodegradable Hydraulic Fluids. SAE Technical Paper No. 932450. SAE International, Warrendale, PA, Troy, MI. https://doi.org/10.4271/932450

[16] Debnath, S., Reddy, M.M. and Yi, Q.S. (2014) Environmental Friendly Cutting Fluids and Cooling Techniques in Machining: A Review. Journal of Cleaner Production, 83, 33-47. https://doi.org/10.1016/j.jclepro.2014.07.071

[17] Bartz, W.J. (2006) Ecotribology: Environmentally Acceptable Tribological Practices. Tribology International, 39, 728-733. https://doi.org/10.1016/j.triboint.2005.07.002

[18] Akagawa, A. (1997) Development of Cutting Fluids Which Are Environment and Human-Friendly. International Journal of the Japan Society for Precision Engineering, 31, 253-256.

[19] Singh, Y., Singh, A.K., Singla, A. and Upadhyay, A.K. (2017) Development and Tribological Characteristics of Bio-Based Lubricant from Jatropha Curcas Oil. Energy Sources, Part A: Recovery, Utilization, and Environmental Effects, 39, 1725-1732. https://doi.org/10.1080/15567036.2016.1252811

[20] Güner, F.S., Yağc1, Y. and Erciyes, A.T. (2006) Polymers from Triglyceride Oils. Progress in Polymer Science, 31, 633-670. https://doi.org/10.1016/j.progpolymsci.2006.07.001

[21] Zhu, F., Fan, W., Wang, A. and Zhu, Y. (2009) Tribological Study of Novel S-N Style 1, 3, 4-Thiadiazole-2-Thione Derivatives in Rapeseed Oil. Wear, 266, 233-238. https://doi.org/10.1016/j.wear.2008.06.016

[22] Onuoha, O.J., Abu, J.O., Lawal, S.A., Mudiare, E. and Adeyemi, M.B. (2016) Determining the Effect of Cutting Fluids on Surface Roughness in Turning AISI $1330 \mathrm{Al}$ loy Steel Using Taguchi Method. Modern Mechanical Engineering, 6, 51. https://doi.org/10.4236/mme.2016.62006

[23] Wilson, B. (1998) Lubricants and Functional Fluids from Renewable Sources. Industrial Lubrication and Tribology, 50, 6-15. https://doi.org/10.1108/00368799810781274

[24] Kuram, E., Ozcelik, B. and Demirbas, E. (2013) Environmentally Friendly Machining: Vegetable Based Cutting Fluids. In: Davim, J., Ed., Green Manufacturing Processes and Systems. Materials Forming, Machining and Tribology, Springer, Berlin. https://doi.org/10.1007/978-3-642-33792-5_2

[25] Zaher, F.A. and Nomany, H.M. (1988) Vegetable Oils as Lubricants. Grasas y Aceites, 39, 235-238.

[26] Willing, A. (2001) Lubricants Based on Renewable Resources-An Environmentally Compatible Alternative to Mineral Oil Products. Chemosphere, 43, 89-98. https://doi.org/10.1016/S0045-6535(00)00328-3

[27] Rahim, E.A. and Sasahara, H. (2011) A Study of the Effect of Palm Oil as MQL Lubricant on High Speed Drilling of Titanium Alloys. Tribology International, 44, 309-317. https://doi.org/10.1016/j.triboint.2010.10.032

[28] Lawal, S.A., Choudhury, I.A. and Nukman, Y. (2012) Application of Vegetable 
Oil-Based Metalworking Fluids in Machining Ferrous Metals-A Review. International Journal of Machine Tools and Manufacture, 52, 1-12. https://doi.org/10.1016/j.ijmachtools.2011.09.003

[29] Kassfeldt, E. and Dave, G. (1997) Environmentally Adapted Hydraulic Oils. Wear, 207, 41-45. https://doi.org/10.1016/S0043-1648(96)07466-2

[30] Pettersson, A. (2007) High-Performance Base Fluids for Environmentally Adapted Lubricants. Tribology international, 40, 638-645. https://doi.org/10.1016/j.triboint.2005.11.016

[31] Adhvaryu, A., Erhan, S.Z. and Perez, J.M. (2004) Tribological Studies of Thermally and Chemically Modified Vegetable Oils for Use as Environmentally Friendly Lubricants. Wear, 257, 359-367. https://doi.org/10.1016/j.wear.2004.01.005

[32] Alves, S.M., Barros, B.S., Trajano, M.F., Ribeiro, K.S.B. and Moura, E. (2013) Tribological Behavior of Vegetable Oil-Based Lubricants with Nanoparticles of Oxides in Boundary Lubrication Conditions. Tribology International, 65, 28-36. https://doi.org/10.1016/j.triboint.2013.03.027

[33] Quinchia, L.A., Delgado, M.A., Reddyhoff, T., Gallegos, C. and Spikes, H.A. (2014) Tribological Studies of Potential Vegetable Oil-Based Lubricants Containing Environmentally Friendly Viscosity Modifiers. Tribology International, 69, 110-117. https://doi.org/10.1016/j.triboint.2013.08.016

[34] Syahrullail, S., Hariz, M.A.M., Hamid, M.A. and Bakar, A.A. (2013) Friction Characteristic of Mineral Oil Containing Palm Fatty Acid Distillate Using Four Ball Tribo-Tester. Procedia Engineering, 68, 166-171. https://doi.org/10.1016/j.proeng.2013.12.163

[35] Koshy, C.P., Rajendrakumar, P.K. and Thottackkad, M.V. (2015) Evaluation of the Tribological and Thermo-Physical Properties of Coconut Oil Added with $\mathrm{MoS}_{2}$ Nanoparticles at Elevated Temperatures. Wear, 330, 288-308. https://doi.org/10.1016/j.wear.2014.12.044

[36] Talib, N. and Rahim, E.A. (2016) The Effect of Tribology Behavior on Machining Performances When Using Bio-Based Lubricant as a Sustainable Metalworking Fluid. Procedia CIRP, 40, 504-508. https://doi.org/10.1016/j.procir.2016.01.116

[37] Fnides, B. and Yallese, M.A. (2008) Cutting Forces and Surface Roughness in Hard Turning of Hot Work Steel X38CrMoV5-1 Using Mixed Ceramic. Mechanics, 70, 73-78.

[38] Ozcelik, B., Kuram, E., Cetin, M.H. and Demirbas, E. (2011) Experimental Investigations of Vegetable Based Cutting Fluids with Extreme Pressure during Turning of AISI 304L. Tribology International, 44, 1864-1871. https://doi.org/10.1016/j.triboint.2011.07.012

[39] Lawal, S.A., Choudhury, I.A. and Nukman, Y. (2014) Evaluation of Vegetable and Mineral Oil-In-Water Emulsion Cutting Fluids in Turning AISI 4340 Steel with Coated Carbide Tools. Journal of Cleaner Production, 66, 610-618. https://doi.org/10.1016/j.jclepro.2013.11.066

[40] Padmini, R., Krishna, P.V. and Rao, G.K.M. (2016) Effectiveness of Vegetable Oil Based Nanofluids as Potential Cutting Fluids in Turning AISI 1040 Steel. Tribology International, 94, 490-501. https://doi.org/10.1016/j.triboint.2015.10.006

[41] Talib, N. and Rahim, E.A. (2015) Performance Evaluation of Chemically Modified Crude Jatropha Oil as a Bio-Based Metalworking Fluids for Machining Process. Procedia CIRP, 26, 346-350. https://doi.org/10.1016/j.procir.2014.07.155

[42] Islam, M., Uddin, M., Alim, M. and Dhar, N. (2009) An Experimental Investigation of Vegetable Oil Based Cutting Fluid on Drilling Medium Carbon Steel by HSS Drill 
Bit. Dhaka ICME.

[43] Kuram, E., Ozcelik, B., Demirbas, E. and Sik, E. (2010) Effects of the Cutting Fluid Types and Cutting Parameters on Surface Roughness and Thrust Force. Proceedings of the World Congress on Engineering, 2, 978-988.

[44] Ojolo, S., Amuda, M., Ogunmola, O. and Ononiwu, C. (2008) Experimental Determination of the Effect of Some Straight Biological Oils on Cutting Force during Cylindrical Turning. Matéria (Rio de Janeiro), 13, 650-663. https://doi.org/10.1590/S1517-70762008000400011

[45] Maruda, R.W., Krolczyk, G.M., Feldshtein, E., Nieslony, P., Tyliszczak, B. and Pusavec, F. (2017) Tool Wear Characterizations in Finish Turning of AISI 1045 Carbon Steel for MQCL Conditions. Wear, 372, 54-67. https://doi.org/10.1016/j.wear.2016.12.006

[46] Xavior, M.A. and Adithan, M. (2009) Determining the Influence of Cutting Fluids on Tool Wear and Surface Roughness during Turning of AISI 304 Austenitic Stainless Steel. Journal of Materials Processing Technology, 209, 900-909. https://doi.org/10.1016/j.jmatprotec.2008.02.068

[47] Safian, S., Hisyam, M.A. and Aman, S. (2009) Evaluation of Vegetable Oil as an Alternative Cutting Lubricant When End Milling Martensitic Stainless Steel Using Uncoated Carbide Tool. Journal of Advanced Manufacturing Technology, 3, 49-56.

[48] Alves, S.M. and de Oliveira, J.F.G. (2008) Vegetable Based Cutting Fluid: An Environmental Alternative to Grinding Process. LCE 2008: 15th CIRP International Conference on Life Cycle Engineering: Conference Proceedings, Sydney, March 2008, 664 .

[49] ManojKumar, K. and Ghosh, A. (2016) Assessment of Cooling-Lubrication and Wettability Characteristics of Nano-Engineered Sunflower Oil as Cutting Fluid and Its Impact on SQCL Grinding Performance. Journal of Materials Processing Technology, 237, 55-64. https://doi.org/10.1016/j.jmatprotec.2016.05.030

[50] Ariff, T.F., Sabiyah, M.Y., Adam, M.A. and Nor, M.A. (2012) Eco-Friendly Machining of T6061 Aluminium Alloy Using Titanium Carbonitride (TiCN) Coated Tools. Advanced Materials Research, 576, 675-678. https://doi.org/10.4028/www.scientific.net/AMR.576.675

[51] Krishna, P.V., Srikant, R.R. and Rao, D.N. (2010) Experimental Investigation on the Performance of Nanoboric Acid Suspensions in SAE-40 and Coconut Oil during Turning of AISI 1040 Steel. International Journal of Machine Tools and Manufacture, 50, 911-916. https://doi.org/10.1016/j.ijmachtools.2010.06.001

[52] Khan, M.M.A., Mithu, M.A.H. and Dhar, N.R. (2009) Effects of Minimum Quantity Lubrication on Turning AISI 9310 Alloy Steel Using Vegetable Oil-Based Cutting Fluid. Journal of Materials Processing Technology, 209, 5573-5583.

https://doi.org/10.1016/j.jmatprotec.2009.05.014

[53] Shaikh, V., Boubekri, N. and Scharf, T.W. (2014) Analyzing the Effectiveness of Microlubrication Using a Vegetable Oil-Based Metal Working Fluid during End Milling AISI 1018 Steel. International Journal of Manufacturing Engineering, 2014, Article ID 261349. https://doi.org/10.1155/2014/261349

[54] Lee, T.S. and Choong, H.B. (2011) An Investigation on Green Machining: Cutting Process Characteristics of Organic Metalworking Fluid. Advanced Materials Research, 230, 809-813. https://doi.org/10.4028/www.scientific.net/AMR.230-232.809

[55] Benardos, P.G. and Vosniakos, G.C. (2003) Predicting Surface Roughness in Machining: A Review. International Journal of Machine Tools and Manufacture, 43, 833-844. https://doi.org/10.1016/S0890-6955(03)00059-2 
[56] Chinchanikar, S., Salve, A.V., Netake, P., More, A., Kendre, S. and Kumar, R. (2014) Comparative Evaluations of Surface Roughness during Hard Turning under Dry and with Water-Based and Vegetable Oil-Based Cutting Fluids. Procedia Materials Science, 5, 1966-1975. https://doi.org/10.1016/j.mspro.2014.07.529

[57] Jia, D., Li, C., Zhang, Y., Yang, M., Wang, Y., Guo, S. and Cao, H. (2017) Specific Energy and Surface Roughness of Minimum Quantity Lubrication Grinding Ni-Based Alloy with Mixed Vegetable Oil-Based Nanofluids. Precision Engineering, 50, 248-262. https://doi.org/10.1016/j.precisioneng.2017.05.012

[58] Sadeghi, M.H., Haddad, M.J., Tawakoli, T. and Emami, M. (2009) Minimal Quantity Lubrication-MQL in Grinding of Ti-6Al-4V Titanium Alloy. The International Journal of Advanced Manufacturing Technology, 44, 487-500. https://doi.org/10.1007/s00170-008-1857-y

[59] Mahadi, M.A., Choudhury, I.A., Azuddin, M. and Nukman, Y. (2017) Use of Boric Acid Powder Aided Vegetable Oil Lubricant in Turning AISI 431 Steel. Procedia Engineering, 184, 128-136. https://doi.org/10.1016/j.proeng.2017.04.077

[60] Nurul Adlina, M.J., Kamaleshwaran, T., Ahamd Fairuz, M. and Azwan, I.A. (2014) A Study of Surface Roughness \& Surface Integrity in Drilling Process Using Various Vegetable-Oil Based Lubricants in Minimum Quantity Lubrication. Australian Journal of Basic and Applied Sciences, 8, 191-197.

[61] Uysal, A., Demiren, F. and Altan, E. (2015) Applying Minimum Quantity Lubrication (MQL) Method on Milling of Martensitic Stainless Steel by Using Nano $\mathrm{MoS}_{2}$ Reinforced Vegetable Cutting Fluid. Procedia-Social and Behavioral Sciences, 195, 2742-2747. https://doi.org/10.1016/j.sbspro.2015.06.384

[62] O'Sullivan, D. and Cotterell, M. (2002) Workpiece Temperature Measurement in Machining. Proceedings of the Institution of Mechanical Engineers, Part B: Journal of Engineering Manufacture, 216, 135-139. https://doi.org/10.1243/0954405021519645

[63] Singh, A.K. and Gupta, A.K. (2006) Metalworking Fluids from Vegetable Oils. Lubrication Science, 23, 167-176. https://doi.org/10.1002/jsl.19

[64] Lligadas, G., Ronda, J.C., Galia, M. and Cadiz, V. (2013) Renewable Polymeric Materials from Vegetable Oils: A Perspective. Materials Today, 16, 337-343. https://doi.org/10.1016/j.mattod.2013.08.016

[65] Lorenz, C.D., Stevens, M.J. and Wool, R.P. (2004) Fracture Behavior of Triglyceride-Based Adhesives. Journal of Polymer Science Part B: Polymer Physics, 42, 3333-3343. https://doi.org/10.1002/polb.20198

[66] Alam, M., Akram, D., Sharmin, E., Zafar, F. and Ahmad, S. (2014) Vegetable Oil Based Eco-Friendly Coating Materials: A Review Article. Arabian Journal of Chemistry, 7, 469-479. https://doi.org/10.1016/j.arabjc.2013.12.023

[67] Samarth, N.B. and Mahanwar, P.A. (2015) Modified Vegetable Oil Based Additives as a Future Polymeric Material. Open Journal of Organic Polymer Materials, 5, Article ID: 53012. https://doi.org/10.4236/ojopm.2015.51001 